\title{
ST. ROBERT BELLARMINE ON THE INDIRECT POWER
}

JOHN COURTNEY MURRAY, S.J.

Woodstock College

$I^{N}$ AN age that is being torn apart by a profound spiritual crisis in the temporal order, it is inevitable that the problem of the relations between the spiritual and temporal should assume ranking importance. No one stands aside from this problem; everyone must adopt some solution for it. Secular theorists of the "new man" are urging the necessary exclusion of the spiritual, in the traditional sense, from any influence on temporal affairs, and are enforcing on man his destiny to be the unaided creator of the conditions of his own free life. Christian theorists solve the problem in terms of their own concept of Christianity and the degree and kind of engagement of religion and the church in the affairs of this world that it permits or prescribes; the orthodox Lutheran or Barthian will differ considerably from the contemporary Protestant liberal or freechurchman. In Catholic terms, of course, the cardinal question is that of the spiritual authority of the Church over the temporal -its bases, extension, fields and manner of exercise, techniques of effectiveness, etc. This is an ancient question, with a complicated history; in the details of its answer there has never been, nor is there yet, complete uniformity of view. Writing in the sixteenth century, St. Robert Bellarmine said: "The fact that there is in the Pope a power in regard of temporal affairs is not a matter of opinion but of certainty among Catholics; although there is no lack of disputes over what kind and manner of power it is ...." Since the sixteenth century some questions have been cleared up; but disputes still go on.

Doubtless they will always go on; for the political theology of the Church (meaning the theology of her relations to the temporal order) will never be a fully "closed" theology. It cannot be, because it is political, and therefore stands in close relation to the contingencies and relativities of the political order, whose institutionalization is con-

${ }^{1}$ De potestate Summi Pontificis in rebus temporalibus, III (Opera Omnia [Neapoli, 1856], IV [Pars 2], 270). 
stantly dissolving. The premises and principles of this theology are indeed firm and unchanging, resting on foundations that stand outside time and the corrosiveness of political change. But there will always remain the task of purifying the developed, practically operative structure of this theology from the contingent elements that necessarily accrue to it in the course of the Church's living through, and wrestling with, the political ideas and institutions of particular ages; there will remain, too, the task of organizing afresh this theology, to insure its exactness, its vitality, and its relevance to new contexts and its solidity against new attacks.

In his own day, St. Robert Bellarmine accomplished this necessary theological task, in its double aspect, with magnificent vigor and sureness. He was, of course, in no sense the inventor of the so-called "indirect power"; but his theological systematization of it was an historical achievement of the first order, immensely influential in his own time, and regarded as classic ever since. At that, his achievement was only historical, not eternal. He did not "fix" the political theology of the Church in final form. In fact, serious difficulties have been raised with regard to the internal consistency of his systematization, and its exactness and adequacy as a statement and interpretation of the tradition of the Church. It may, then, be useful to look at his system. Perhaps a consideration of the problems that it raises may lead to another more profound, delicate, and vexing problem - that of the development of the Christian tradition on the power of the Church in temporal affairs, and of the two levels of thought that tend to appear in any theological interpretation of the tradition - the level of the absolute and permanent, and the level of the contingent and historically conditioned.

A study of the theory of the indirect power might have another, secondary usefulness. From the Catholic doctrinal and pastoral standpoint the contemporary question-emphasized with great force in papal documents of the last half-century -is that of the authority of the Church in the field of temporal affairs. However, by a curious quirk, from the polemical standpoint the contemporary question has become that of the power of secular government in the affairs of religion. The controversy in the United States that has arisen over "Church and State" is being carried on in this narrow state of the 
question. It is, of course, natural that such a debate should arise in the world of today, whose primary concern is the limitation of political sovereignty by the rights of man, especially his rights in all the affairs of the spirit. However, from the Catholic standpoint it is unfortunate that so much importance should be attached to the narrow issue of the "rights of Catholic governments" to limit by coercive law the public manifestation and propaganda of non-Catholic sects.

First, within the scheme of Catholic doctrine, these asserted "rights," whatever they may be, constitute a minor and peripheral issue. Secondly, this issue has a long and rather murky history, and it resists capture in the simplistic formulas that prevail in popular controversy; it demands consideration in broad doctrinal and historical perspective, and consequently one does rather badly with it on the journalistic level beloved by our Methodist and Baptist friends. For my own part, I am uneasy on seeing the issue disposed of by some resounding generalization: "Error has no rights"; or, "The power of God in the State must assist the power of God in the Church"; etc. In their generality, the generalizations are true enough; the trouble is with their generality. One strongly wishes that our non-Catholic brethren might be presented with the integral Catholic doctrine, about which they are troubled; but the presentation is not accomplished by generalizations. This is no question to be dealt with "in a few simple ideas." Bellarmine once rebuked an "integrist" of his own day, Alexander Carerius, for the simplism of his views on the power of the Pope in temporal matters, which overlooked the complications of the question and hence missed the question itself: "Since he does not discuss the manner (in which the Pope possesses this power), and thus ignores the state of the question, all the arguments of Carerius and authors like him are idle; not only are they of no help to the ecclesiastical power but they are even disastrous to it, since without reason they make it odious to the princes of the world."'bis Bellarmine himself said many odious things to the princes of the world, and even of the Church, but always with reason.

My own suggestion is that an integral statement of the duties and rights of secular government in the field of religion cannot be made save

1bin Epistola Apologetica Roberti S.R.E. Cardinalis Bellarmini ad Franciscum Card. Sancti Clementis adversus temeritatem et errores Alexandri Carerii Patavini, in LeBachelet, Auctarium Bellarminianum (Paris, 1913), p. 434. 
on the basis of a prior statement of the rights of the Church in the field of politics. Whatever rights the government of a Catholic people may have in the field of religion (understanding supernatural religion), it has them only in consequence of the subordination of its end to the end of the Church. This same subordination gives the Church a certain power in the field of politics. The two problems rise out of the same root, and are therefore analogous. And the solution given to each must be symmetrical with the solution given to the other. This is true a priori; it is also true historically. Always the prior problem has been that of the power of the Church. The principles governing its solution likewise governed the solution of the secondary problemthe power of the State. And the concrete solution given to the prior problem by the application of principles to a particular historical situation has been reflected in the concrete solution given to the secondary problem. This is why I think a study of the indirect power of the Church in temporal matters should assist in clarifying the minor issue raised in our contemporary controversy.

\section{BELLARMINE'S CONCEPT OF THE INDIRECT POWER}

Bellarmine stated his theory as a young man of 44 in the first volume of the Controversies, in the Controversy, On the Supreme Pontiff, the Fifth Book, "On the Temporal Power of the Pope." ${ }_{2}$ He dealt at length with one of the historical elements of the problem in his treatise, On the Translation of the Roman Empire. ${ }^{3}$ He returned on certain of his premises in the second volume of the Controversies, in the Controversy, On the Members of the Church, the Third Book, "On the Laity," which is, he says, a treatise "on the political magistracy." 4 Thereafter he defended his position in the three major conflicts that took up a good part of his life: (1) against the "seven fools" of Venice in the dispute chiefly over clerical exemption $(1606-7) ;{ }^{5}(2)$ against the royal

2Opera Omnia (Neapoli, 1856), I, 524 ff.; cited hereafter as De S. Pont., V, with the chapter, and reference to the page in this edition.

${ }^{3}$ Ibid., IV (Pars 2), $38 \mathrm{ff}$., especially c. XII, pp. $78 \mathrm{ft}$.; the work was written in 1583-84, but not published till five years later; cf. E. A. Ryan, The Historical Scholarship of St. Bellarmine (New York, 1936), p. 157.

${ }^{4}$ Opera Omnia, II; especially cc. XVII-XXII, pp. 333 ff.

5 Risposta del Cardinale Bellarmino al trattato dei selte teologi di Venewia, ibid., IV (Pars 2), 455 ff.; Risposta del Cardinale Bellarmino a due libretti ..., ibid., pp. 479 ff.; Risposta 
absolutism of James I of England (1607-9); $;^{6}(3)$ against the equally absolutist and also Gallican ideas of William Barclay, ${ }^{7}$ and Roger Widdrington (1610). ${ }^{8} \quad$ Finally, he touched one or other point in some of his minor writings. ${ }^{9}$ The statement given to his thought in the early treatise, "On the Temporal Power of the Pope," is essentially complete; his later works clarify and develop it a bit, without altering its lines and substance.

Bellarmine's dominant preoccupation was, of course, the defense of Catholic tradition; he is embarrassed when the adversaries of the Church single him out for attack. "I am not so important," he writes in the preface to the book against Barclay, "as to think that the cause of the universal Church hangs on me alone. I know my imperfections; I know that I am only one of many; and I will not allow that the common cause should be prejudiced, whether I stand or fall in this debate." 10 The common cause had been put in jeopardy by the errors of Wicleff, the anarchistic "Spirituals," Marsilius of Padua, and the Reformers; by the errors of the English and Gallican theorists of royal absolutism; and by those of the "many canonists ... and not a few others" 11 among Catholics who had, as they thought, defended the papal cause against earlier and later medieval and Renaissance regalists; they are usually called the "hierocrats." Bellarmine's refutation of all these errors is crushing. Basically, it is a dogmatic refutation by appeal to tradition - the acts and teaching of the Church, the Scrip-

del Cardinale Bellarmino alla difesa delle otto proposisioni di Giovanni Marsilio, ibid., pp. $511 \mathrm{ff}$.

${ }^{6}$ Roberti S.R.E. Card. Bellarmini Responsio ad librum inscriptum, Triplici nodo triplex cuneus, ibid., pp. 417 ff.; A pologia Roberti Bellarmini S.R.E. Card. pro responsione sua ad librum Jacobi, ibid., 347 ff.; Hieratikon Doron, sive modesta et fidelis admonitio Roberti Bellarmini S.R.E. Card, ad Jacobum Magnce Britanniae Regem, Auclarium, pp. 209 ff.

${ }^{7}$ Tractalus de potestate Summi Pontificis in rebus temporalibus adversus Gulielmum Barclaeum, Opera Omnia, IV (Pars 2), 259 ff.; cited hereafter as De potestate, with the chapter, and page in this edition.

"Roberli S.R.E. Card. Bellarmini Examen ad librum falso inscriptum, A pologia Card. Bellarmini pro jure principum, auctore Rogero Widdrington Catholico anglo, Auctarium, pp. $358 \mathrm{ff}$; on the history of this book, cf ibid., pp. 205-206; cited hereafter as Examen, with the chapter, and the page in this edition.

- Especially the Epistola Apologetica against Carerius, cited supra, note 1 ; in the Auctarium there are several other pertinent items.

${ }^{10}$ De potestate, Praef., p. 259.

"De S. Pont., V, 1, p. 524.

${ }^{12}$ Cf. F. X. Arnold, Die Staatslelire des Kardinals Bellarmin (München, 1934), pp. 296-305. 
ture, the Fathers and Doctors. In these sources Bellarmine finds the principles that integrate Catholic tradition and outlaw the current errors.

However, in the course of his refutation of these errors Bellarmine drew from his theological sources a description of the indirect power, a set of arguments for it, and a list of its implications in the political order. In particular, he gave an interpretation of the acts of the medieval papacy; he newly applied to the problem of the two powers the Thomistic doctrine of the natural origin and end of the temporal power; and he stated certain empowerments of the political power within the respublica christiana. In other words, in connection with his dogmatic refutation of errors in regard of the power of the Church in temporal affairs he also constructed a theological theory of the indirect power. As a theory -in its manner of expression, the argumentation in its supports, its stated implications - it has not been canonized by the Church. There has been freedom to criticise and modify it, and the freedom has in fact been used.

The latest of Bellarmine's many definitions of the indirect power is in his Recognitio Operum: "We understand by jurisdiction of an indirect kind the jurisdiction which the Pope has over the temporal in its relation to the spiritual; properly and of itself his jurisdiction regards the spiritual." 13 From his earliest writings he regards this as the "middle view" common to Catholic theologians, that "the Pope as Pope directly and immediately has no temporal power but only a spiritual power; nevertheless by reason of his spiritual power he has at least indirectly a power in temporal things, which is a supreme power (eamque supremam)."14 The same view is stated over and over again in the book against Barclay:

By the words 'direct' and 'indirect' we do not mean, as it has been jokingly said, that the spiritual power is in the Pope directly, that is, lawfully and legitimately, and the temporal power indirectly, that is, unlawfully and by usurpation. Rather we mean that the papal power is of itself properly spiritual, and therefore directly regards as its primary object spiritual affairs; but indirectly, that is, by reason of their relation to spiritual things, reductively and by necessary consequence it regards temporal things as its secondary object. To this object the spiritual power turns, as Innocent III says, in particular cases (casu)..$^{15}$

is Opera Omnia, IV (Pars 2), 235.

is De potestate, V, p. 278.

${ }^{14}$ De S. Pont., V, 1, p. 524. 
In regard of all other Christian provinces and Christian princes [outside the papal States] (theologians) accord to the Pope only a spiritual power, which of itself properly regards only the spiritual, and regards the temporal only as it is subordinate to the spiritual. And therefore, when we speak properly, we say that the Pope has a power in the temporal, but as Pope he has no temporal power. From which it follows that the difference conveyed by the terms 'direct' and 'indirect' does not refer to the manner of acquiring the power, as Barclay falsely asserts; the words are used to set forth the secondary and consequent object of the supreme spiritual power, which primarily and directly regards the spiritual, and regards the temporal secondarily and indirectly, that is, in its relation to the spiritual. ${ }^{16}$

It is evident that Bellarmine wanted to lay primary stress on the power of the Church as single in itself and solely spiritual. So, again, in lecturing Carerius on his ignorance, he says that no theologian denies that the Pope "has fullest and most ample power over spiritual and corporal things; but the question concerns the manner-has the Pope one power, properly spiritual, which stands so high over all temporal powers that by it he can dispose of all temporal things, or has he two distinct powers, one spiritual and the other temporal, both by divine right, in such wise that St. Peter was established by Christ as King of the world as well as Pope?"17 The latter was the view of the hierocrats, shared by Carerius; Bellarmine consistently rejected it, so definitely that he got into trouble with Sixtus $V$ and escaped the Index only by that fierce Pope's timely death.

Spiritual in itself, the power of the Pope "extends" to the temporal order casu, on occasion. The occasion is created "by a serious reason, especially a concern of faith,"18 "the salvation of souls, the welfare of religion, the preservation of the Church," 19 or more in general, a "necessity of the Church." 20 Moreover, the occasion is created by some deviation or default of the processes of the temporal order, that results in a spiritual danger. Judgment as to the existence of the occasion and its gravity rests, of course, with the Pope; but he may not "at his pleasure falsely devise necessities," and he must always act in view of a spiritual end. ${ }^{21}$

The intervention of the Pope, when the occasion is there, takes two forms, a positive and a negative one. Bellarmine's general formulas

\footnotetext{
${ }^{16}$ Ibid., XII, p. 294.

18 Examen, VI, p. 368

${ }^{20}$ De. S. Pont., V, 7, p. 532.
}

${ }^{17}$ Epist. A pol., Auctarium, p. 432.

10 De potestate, III, p. 270.

a Ibid., 4, p. 526; De potestate, XII, p. 295. 
are the medieval ones - to direct (dirigere) and to correct (corrigere), to which is added the even more general one, to judge (judicare). ${ }^{22}$ Rather characteristically, Bellarmine does not analyze these concepts to see if there be a difference between two cases: (1) when the good of religion is directly attacked, and the Church intervenes to forbid (a negative intervention ratione peccati - a phrase Bellarmine does not use), and (2) when the good of religion is indirectly compromised by way of extrinsic consequence of some political act or omission; in which case the Church intervenes to prescribe (a positive intervention ratione boni Ecclesiae). He maintains roundly that the power of the Church extends to temporal things "insofar as they help to open the kingdom of God to the faithful, or are a hindrance and an obstacle to its being opened to them." And the following three special modes of intervention are characteristic of his thought:

In regard of persons, the Pope as Pope cannot by ordinary jurisdiction (ordinarie) depose temporal rulers even for a legitimate reason, after the manner in which he deposes bishops, as their ordinary judge; nevertheless as the supreme spiritual ruler, he can change the royal power, taking it away from one and conferring it on another, if this be necessary for the salvation of souls....

In regard of laws, the Pope as Pope cannot by ordinary jurisdiction make a civil law or confirm or invalidate the laws of princes; for he is not himself a political ruler of the Church (ecclesiae; note Bellarmine's use of this word for the civil order of Christendom); nevertheless, he can do all these things, if a particular civil law is necessary for the salvation of souls and the prince is unwilling to pass it, or if a particular law is harmful to the salvation of souls and the prince is unwilling to abrogate it....

In regard of judicial sentences, the Pope as Pope cannot by ordinary jurisdiction decide civil cases. ... Nevertheless, in a case in which this is necessary for the salvation of souls, he can assume civil jurisdiction, when, for instance, there is no one else to give judgment (as when two kings are in conflict), or when those who could and should give judgment are unwilling to do so....24

Bellarmine also put a close connection between the indirect power of the Church and the duty of the State to "exterminate" heresy; however, this is another subject.

The defense of the indirect power which Bellarmine all his life put

${ }^{2}$ Cf. De S. Pont., V, 6, p. 532; De potestate, II, p. 269; III, pp. 270, 271; V, p. 278; XIV, p. 300 ; XXV, p. 318 ; XXXI, p. 327; etc.

${ }^{23}$ De potestate, V, p. 279. ${ }^{24}$ De S. Pont., V, 6, p. 532. 
up was a defense of these forms of its exercise; and the greatest weight of his argument went behind the power to depose secular rulers. This is the thing that chiefly stuck in the throat of James I; it is mentioned twice in the famous Oath of Allegiance, ${ }^{25}$ over which Bellarmine had his battle with the King. And it furnishes the dominant theme in the controversies with Barclay and Widdrington. Bellarmine was willing to let it be the experimentum crucis; he was likewise ready to qualify his opinion up to the hilt: "Although one might perhaps question whether the negative opinion (denying the papal power of deposition) should properly be called a heresy directly and in the first instance, still there can be no doubt that it is rash, erroneous, and heretical at least reductively and secondarily ...; f for from it would follow that the Church can err in faith, and that the Pope has not sufficient power to rule the faithful, and other things which by common consent are heretical." ${ }_{26}$ I should add, too, that Bellarmine was thinking of a power genuinely to depose a king, and not simply declare him deposed. ${ }^{27}$

\section{Direct or Indirect?}

It is difficult to see why the canonists should have gone running to Sixtus V, crying that Bellarmine had shortened the arm of the papacy and given comfort to its enemies by denying to the Pope a direct temporal power. ${ }^{28}$ The modern question is, whether he did at bottom really deny the direct temporal power, or merely trim it down to size. The question has been raised, whether his theory is in its conclusions consistent with its own premises. Its basic premise is that the Church's power is single, and solely spiritual, that she has not by divine right any merely temporal jurisdiction. That is, I take it, she has no power directly and immediately to produce juridical effects within the temporal order. But as seen in the decisive instances of its use, Bellarmine's indirect power appears as more than simply a spiritual

${ }^{*}$ Cf. J. Brodrick, Blessed Robert Bellarmine (New York, 1928), II, 173.

* Examen, VI, p. 368.

${ }^{27} \mathrm{Cf}$. De potestate, XXXVI, p. 335: "Although the loss of reign or empire does not follow by sheer force of excommunication, except in cases of heresy or apostasy, still the Pope, who can suspend jurisdiction by excommunication, can also take away all jurisdiction and royal power by deposition."

${ }^{2 s}$ Cf. Brodrick, op. cit., I, 269-70. 
power that extends itself into the realm of the political; rather, it seems that in the course of the extension the power itself has ceased to be purely spiritual and become formally temporal, specified as such by an act that is formally political: by act of the Church a political status has been altered (this king is no longer king), or there is now a new civil law, or this civil case is now formally closed.

Moreover, these temporal effects are directly willed in themselves, as means to a spiritual end; the spiritual is reached through the temporal. The fact that in producing these effects the Church uses her power only for a spiritual end does not help; for the nature of a power is not altered by the motives or end of its use, and a political effect, even though produced in the high interests of the Church, is for all that a political effect. Nor does it do to say that the Church acts in this way only casualiter; the question is whether she may ever so act, given the nature of her power as purely spiritual. Finally, it does not settle the difficulty to distinguish two fields, one primary and spiritual and the other secondary and temporal, wherein the Church may act; the question, on Bellarmine's premises, is whether the power of the Church, even as operative in its secondary temporal field, is still a purely spiritual power. In other words, the crucial question is not whether the Church may defend herself and the faith of her children when it is attacked or endangered, nor whether she must meet all moral issues wherever they may arise, nor even whether she may somehow direct and correct the temporal power; the answer to these questions is certainty affirmative. The question is whether she may do all these things tali auxilio - by laying her hands directly on the processes of the temporal order (whereby kings are seated or unseated, laws are passed, etc.). The answer here, if one want to be consistent with the doctrine that the Church's power is purely spiritual, ought to be negative.

On such grounds as these it has been said that Bellarmine, after thrusting out the theory of the direct power as an error, brings it back in, considerably modified but substantially itself. He does indeed deny the assertions of the hierocrats on the origin of political power; it does not originate in the fact of sin nor is it given to the prince mediante papa; it takes its origin from the law of nature and is resident in the prince by the law of nations. Similarly, Bellarmine denies to 
the Pope the ordinary possession of the two powers. Nevertheless, the essential point seems to remain - in both theories the Church can exercise a political power in her own right. Bellarmine's indirect power seems to be simply a direct power restricted to exceptional use; but if the Church uses it she must have had it; and in that case the power of the Church is not solely spiritual. Bellarmine's restrictions and distinctions hardly alter the substantial case. After all, even the hierocrats insisted that the Church might use her temporal power, not arbitrarily nor in the ordinary run of affairs, but only when the higher interests of religion were engaged. And they likewise asserted that the root of the Church's power in the temporal order was her divine commission as spiritual ruler of mankind.

It would seem, then, that between the hierocrats' theory of the direct power and Bellarmine's theory of the indirect power there exists in the last analysis "a difference more apparent than real," as Moulart says. ${ }^{29}$ More recently De Lubac has found in it a "lack of logic": "Its premises should lead to conclusions of another order. At first sight, one feels the satisfaction of clarity; but reflection quickly reveals it as a bastard compromise, and an untenable one, between the theory of the direct power and that of the directive power." ${ }^{30}$ Criticisms to the same general effect were made long ago, most pertinently perhaps by Bianchi, who refined Bellarmine's theory into a form of his own, that has found many followers and deserves a special study. ${ }^{31}$

I think that the main point in these criticisms is well taken. But two things should be understood. First, the criticism affects only Bellarmine's systematization, and leaves untouched the solidity of his defense of the essential data of Catholic tradition. Secondly, it does not detract from the remarkable nature of his historical achievement; actually, it merely means that Bellarmine did not say the last word on the subject, though the word he said was the best that had yet been said. As a matter of fact, no one before him, not even the great Vittoria, had managed to work quite so far through the two major

${ }^{20} \mathrm{~F}$. Moulart, L'Église et l'État (Paris, 1887), p. 195.

${ }^{30} \mathrm{H}$. de Lubac, "Le pouvoir de l'Église en matière temporelle," Revue des Sciences Religieuses, XII (1932), 335; cf. in the same sense, J. Lecler, L'Église et la souveraineté de l'État (Paris, 1944), pp. 101-104.

"I $I$ expect to take it up in a later article that will deal with the theory of Jean Quidort (John of Paris). 
difficulties that had confronted all Catholic theorists of the papal power in the temporal order from the time they began seriously to theorize - say, with John of Salisbury. Both of these difficulties really form part of a single overriding problem - that of the development of doctrine, especially in regard of this doctrine, which has perhaps seen, and will still see, more development than any other.

\section{BELLARMINE'S PROBLEM}

The first and most obvious difficulty derived from the massive fact of medieval Christendom - the intricate system of relationships that had been built upon between regnum and sacerdotium - and the soaring idea that in part inspired, and was in part inspired by, the fact; I mean the idea of the one respublica christiana, that conceived the Empire as existing within the Church and making with it one society, one $c c$ clesia, with a dual administrative hierarchy that found its unity in the headship of the Roman Pontiff. How was one to analyse in terms of doctrine this massive social and juridical fact? How, in particular, was one to interpret the acts of the medieval papacy, that stood at the center as well as at the summit of this one factual entity that men called christianitas? Fully to appreciate the difficulty, it should be remembered that in the complex matter of the relationship between the two powers action always had the primacy over theory; the doctrine that was always "there" emerged, as it were, as concrete situations were met by concrete measures. Perhaps more exactly, the principles that guided action became matter for reflection only as they appeared in the action itself; however, since the action was designed to meet the exigencies of the contingent social situation in which the two powers met (usually in conflict), the principles could only with difficulty be seen in their clarity and purity; indeed it may be said that their full clarity and purity never appeared in any act, because every act had a context that tended to obscure its inspiration.

The second difficulty operated to complicate still further this problem of doctrinal analysis; it was the lack of a fully articulated and organized political philosophy, firmly possessed in itself and in its implications for the relations of the two powers. This lack of a philosophy of the State corresponded in a way to a certain absence of the State itself during the early and high Middle Ages. In the thir- 
teenth century, of course, St. Thomas formulated the necessary philosophy; but living at a time when, in the phrase that he once uttered, "kings are vassals of the Church," ${ }_{22}$ he had not felt obliged to work out the implications of the autonomy of the political order that his philosophy asserted. During the fourteenth and fifteenth centuries men for the most part lost hold of his philosophy. Drawn from antiquity, it embodied a middle position between the competing theories of the time, and could not be popular with either; for it put a check both on the hierocrats, supporters of the old position of the Pope in relation to the Empire, and on the legists, supporters of the rising national polities, chiefly in France, which in becoming national were growing to a new consciousness of Statehood and were finding in the national monarchy a newly intense focus of their political life. The Thomistic political philosophy was the valid support and explicitation of the ancient Gelasian doctrine of the two separate powers within two distinct societies; but in an age of intellectual decadence and political turmoil it had no chance to make its way. One sees it grasped by men like John of Paris; but it still had as a serious rival the theory called "political Augustinism," that explained in quite other terms the origin of political power, its functions, and its distinction from the ecclesiastical power.

It was perhaps the absence of a sound political philosophy that explains the prevalence even in the sixteenth century of hierocratic ideas and the hierocratic climate of opinion. If not in possession, the theory of the hierocrats was at least powerful enough - in the Curia, not so much in the School, after the Dominican revival of Thomism in Salamanca - to have brought Bellarmine and Vittoria to the edge of the Index. Moreover, as Bellarmine himself points out, ${ }^{33}$ it was from this philosophical vacuum, as filled by a false theologism and biblicism, that there came forth the two opposite errors that are nonetheless akinthe papalocaesarism of the hierocrats and the caesaropapism of Wicleff and the Reformers, as well as the Jacobine theory of the king as "utriusque tabulae custos,",34

It is Bellarmine's singular merit, acknowledged by all, that he newly organized and revivified the Thomistic philosophy of political power

"Quodl. XII, q. 13, a. 19 ad $2 \mathrm{~m}$.

"De S. Pont., V, 4, p. 527.

"Hier. Doron, XVI, Auctarium, p. 234. 
as natural in origin, temporal in end and field of competence; thus he clarified afresh the radical distinction of the two powers that was denied or obscured alike by Reformers, regalists, and hierocrats. This firm rational construction was his major weapon against the errors he opposed; and together with his powerfully developed ecclesiology, it served to give new solidity and soundness to the Church's political theology. The point is too well known to need further elaboration.

But the question that needs to be asked is whether Bellarmine exhausted the virtualities for the development of Catholic doctrine that are inherent in the natural-law concept of the temporal power and of the State it orders. Widdrington's prime indictment was that Bellarmine dethroned the regia maiestas by his denial of the doctrine of divine right, in order to exalt the papal throne; ${ }^{35}$ and later Gierke accused him of using his philosophical concept of the State simply as a club with which to beat the State into subjection to the Church. ${ }^{35}$ The accusation is false, of course; but there is this much truth in it, that Bellarmine used his political philosophy primarily as an argument against the royal absolutists, not against the hierocrats. The whole tendency of his argument from the natural-law concept of the temporal power is indeed to prove its subordination to the spiritual power by reason of its inferior finality. To this extent Gierke has a specious handle for his accusation. Bellarmine's polemical preoccupations did not permit him to go deep into the idea that is of such great contemporary importance to us - that the finality of the temporal power, though inferior, is a genuine finality in its own right, that bases a large autonomy of the State. Moreover, living in an age of relatively undeveloped social economy, as well as in an abstract and simple theological universe, he could not envisage the immense services that are rendered to the Church by the temporal power when it simply fulfills its own finality in the natural, temporal order. Since his problem was narrow, Bellarmine's concept of the autonomy of the State is jejune, as his concept of the subordination of the temporal to the spiritual power is rather bloodless, from our contemporary point of view, established by the social encyclicals. Were he writing it today, his treatise, "On the Power of the Pope in Temporal Affairs," would have to wrestle with

s Cf. the citation from the Examen, apud Arnold, op. cit., p. 125, note 39.

36 Cf. Arnold, op. cil., p. 324. 
a vastly enlarged and complicated problematic, and make much more extensive use of the Thomistic concept of the State.

I would note here, too, that Bellarmine makes very little use of this concept against the hierocrats. In his refutation of them (discreetly brief, for the subject was "hot") he is content to meet them primarily on their own ground, which was scriptural and theological. His essential challenge was to their concept of Christ as temporal King in his human nature, whence derived the concept of the Pope as dominus orbis. $^{37}$ Moreover, his single quarrel with them was in regard of their fundamental error, which regarded the origin of political power. $\mathrm{He}$ dismisses it curtly with a reference to the substance of his political philosophy: "Dominion is not founded on grace or faith, but on free will and reason; nor does it derive from divine law but from the law of nations." "'s8 However, he does not seriously come to grips with the other idea that played so large a part in hierocratic theory - the idea of the instrumentality of the temporal power in regard of the ends and purposes proper to the spiritual power-chiefly the maintenance of her own unity and the integrity of her faith against attack by heretics.

As a controversialist, he does indeed deal thoroughly with the active question, whether the temporal power is a judge in religious controversy. And in his negative answer, he appeals to a fertile principle: the secular power "can do nothing beyond the empowerment (virtutem) it receives from its causes; now the causes of secular magistracy are human and natural; the efficient cause is the election of the people, the end is the peace and temporal tranquillity of the commonwealth; therefore the ruler as such has empowerment and authority only of the human order, such as the people can give and such as is required for the preservation of temporal peace."'39 It is not, then, a judge of religious truth. The principle of Durandus, twice cited, leads to the same conclusion: "The temporal jurisdiction in no way extends to the spiritual, about which it knows nothing." 40 Finally, against the royalist objection: "But, it is said, kings are kings even in the Church, and Christians ought to be subject to them tamquam praecellentibus.

${ }^{37}$ De S. Pont., V, 4, pp. 526-28; Recognitio Operum (Opera Omnia, IV [Pars 2], pp. 235-38).

as De S. Pont., V, 2, p. 525.

as De Verbo Dei, III, 9 (Opera Omnia, I, 111).

${ }^{40}$ De S. Pont., V, 5, p. 531; De potestate, Praef., p. 262. 
This is true enough, but only in regard of those things which belong to the political order; for Christian kings have power over Christian men, not inasmuch as they are Christians but inasmuch as they are men, just as at times they have power over Jews and Turks, but inasmuch as they are political subjects (homines politici)." 41

These, I say, are fertile principles, but in Bellarmine they are barren of all save the single consequence, that secular rulers are not judges of religious truth. They are not carried over into the large question opened, for instance, by Giles of Rome when he says: "The royal power is established through the medium, and by the agency, of the ecclesiastical power, and given as its finality the business and obedient service of the ecclesiastical power." ${ }^{2}$ More exactly, Bellarmine uses his principles to dispose of the first part of this imperial piece of clericalism - the origin of the temporal from the ecclesiastical power; but he does not make them relevant to the second part-the instrumentality of the secular power in regard of the ecclesiastical. This, of course, is an important part of our modern problematic, but it did not enter into Bellarmine's. The fact, I think, is that he was shut off from it by the first of the two great difficulties that I mentioned above. In consequence, it may again be asked whether his theory of the indirect power is not reductively a theory of a direct power-this time insofar as his concept of the subordination of the temporal to the spiritual power involves the instrumentality of the former to the latter that was an essential rib of the direct-power theory. However, leaving this question for the moment, let us look at the difficulty presented to him by the medieval fact. It is a difficulty that still plagues Catholic theorists on Church-State relationships; and if Bellarmine did not fully think through it, he may well be pardoned; I suspect it has not been wholly thought through even yet. Certainly it is the root of whatever inconsistencies, inadequacies, and obscurities there are in Bellarmine's theory of the indirect power and in his arguments for it.

The fact is that the initial, assumed premise of Bellarmine's whole

${ }^{4}$ De S. Pont., V, 7, p. 321.

42 "Potestas regia est per potestatem ecclesiasticam et a potestate ecclesiastica constituta et ordinata in opus et obsequium ecclesiasticae potestatis" (De pot. eccl., II, 5; cited by Gierke, Political Theories of the Middle Ages, transl. Maitland [Cambridge, 1913], p. 111, note 18 ). 
thought is the famous "dream of Origen" in its medieval realization The overarching concept of Boniface VIII in the Bull Unam Sanctam likewise arches over Bellarmine's pages; I mean the medieval principle of unitarism. It is less rigidly controlling, but its influence is felt in every aspect of the whole question. Even in Bellarmine's language it appears; on innumerable occasions he uses the word "Church" (ecclesia) to designate in the medieval manner the one social reality that was both Church and State, the one respublica Christi, within which were two orders of life, two folks, two powers. It is significant, too, that his treatise "on the political magistracy," 43 is in the Controversy, On the Members of the Church, in the section dealing with the laity; the laity are the bearers of political power, but it is borne by them within the one Church. Though he does not push the principle of unitarism to the same lengths as many of his predecessors, his whole treatment of the problem of the two powers proceeds in terms of this fundamental medieval category. Or to speak more exactly, in dealing with the problem he has before his mind, not so much a category as a fact - the medieval fact. In a true sense his theory is an attempt at theoretical formulation of this fact-at articulation in terms of principle of a particular segment of history.

It has been pointed out that his thought always tended to the concrete; he did not construct a theory of relations between the Church and the State, understanding the State as an abstraction. ${ }^{44}$ In this regard his universe of discourse was different from that of theologians of the nineteenth century. It was not his problem, as it was theirs, to prove that the State as such ought to be "united" with the Church as such for reasons deriving from the abstract nature of each, and that the fact of their separation was iniquitous. Bellarmine's starting point is an opposite fact - that of the unity of the two powers within the one respublica christiana; and his effort is to prove that within this one Christian commonwealth (which he always conceived to be existent), the Church has a power over temporal affairs that extends notably to the deposition of Christian rulers turned heretic. Moreover, in discussing this problem he takes its terms concretely. One is the uni-

${ }^{40}$ De laicis, I'(Opera Omnia, II, 313).

" CC. J. Gemmel, "Die Lehre des Kardinals Bellarmin uber Kirche und Staat," Scholastik, V (1930), 371. 
versal Church whose head is the Pope; the other is the ethnarchy, the Empire, the ruling power over the populus christianus, the Christendom that was at least in destiny as universal as the Church. The formal terms of his problem are essentially medieval, not modern.

He never went into the problem put to the Church by the modern concept of national sovereignty, nor by the identification of Church and "nation" that was a post-Reformation development, nor by the alliance of the Church with the principle - and not seldom the passionof nationalism. Being concerned with the ethics and not with the facts of social life, he gave no place in his theories to the "nation," a particularist society with a unity of its own that is spiritual in a genuine sense, but not created by the spiritual unity of the Church; for it is formed by what Barker has called the "common mental substance resident in the minds of all its members," 45 and resultant from a common tradition, a public opinion, a general will, a pervasive and unitary climate of feeling. The nations were not born of the Church; much less was nationalism. On reading Bellarmine, one might suppose that they had not been born at all; that the problem of the spiritual and the temporal was that of the relations of two authorities within the one society - between kings and popes - and not that of the relations between two societies - the Church and the nation - both of them somewhat in eodem genere, inasmuch as the nation-State considered itself at once a spiritual society and a "perfect" society.

Bellarmine could argue his problem in a medieval state of the question because, as a theologian, he was arguing it from books. And in all the many books he read the terms of the problem were the two powers within the one society - the sacerdotium and the imperium (or the regnum as englobed within the imperium) whereby the one Christian commonwealth was ruled. The books could take these as the terms of the theoretical problem because they were also the terms of the practical problem at the time the books were written. And Bellarmine, as a theorist, did not feel called upon to advert to the fact that the problem, on these particular time-conditioned terms, had ceased to exist. For all practical purposes the respublica christiana, as an operative political reality, had perished with the death of Boniface VIII in 1303; the rise of the nation-State disrupted its essential

s E. Barker, Cluarch, State and Study (London, 1930), p. 136. 
pattern, and the Protestant revolt destroyed its very foundations, the religious unity of Europe. Historic christianitas in Bellarmine's day was no longer a problem because it was no longer a fact.

However, Bellarmine could continue to consider it a problem, not only because it was the problem of his books, but also because he shared the general view of his contemporaries, which hung on till the peace of Westphalia, that the religious division brought in by Protestantism was merely a passing phenomenon; that the restoration of religious unity was only a matter of time; and that the time could be hastened by continued strong assertion on the part of the Church, with the aid of the power that she had historically come to consider her secular arm, of all her formerly acknowledged rights over a baptized Europe. This last judgment was particularly mistaken, but the mistake was natural. When a problem is perennially valid, as is that of the power of the Church in the temporal order, it is difficult for men to realize that the precise terms in which it is posited in a particular age have not the same perennial validity. Bellarmine rightly knew that the principles governing the solution of his problem could not be invalidated by any historic happenings; but he failed to realize that all that happened since Philip and his lawyers successfully defied Boniface had moved the problem into a new phase by profoundly altering its whole context. In this new context the old principles were still valid, but the newness of the context required their renewal, their purification from a manner of statement and application that was only valid in the old context.

Bellarmine's adherence to the old context is nowhere more apparent than in his use of the famous body-and-soul metaphor of Gregory Nazianzen, as the central image in which an intuitive glimpse is had of the relations of the two powers. The metaphor itself, of course, is valid, but vague; in fact, I should say that its validity is dependent on its vagueness. But Bellarmine, like medieval men before him, filled it out to full flesh-and-blood proportions, by drawing, not so much on Catholic doctrine as such, as on a time-conditioned conception of the organism of society. "The two powers in the Church," he says, "are as flesh and spirit in a man." And this round statement carries him at one step way beyond Gregory Nazianzen into the world of Hugh of St. Victor. Spirit and flesh can exist separately, he goes on, as in angels and beasts; and each has its own acts and ends. But when they 
"make one person, there is necessarily a relation of subordination" of flesh to spirit.

In exactly the same way, the political power has its princes, laws, tribunals, etc., just as the ecclesiastical power has its bishops, canons, tribunals. The former have for their end temporal peace; the latter, eternal life. They are at times found separated, as of old in the days of the Apostles, and at other times conjoined, as at present; but when they are conjoined they make one body; and consequently they must be related, with the inferior subject and subordinate to the superior.

Moreover, the similarity extends to the manner of subordination. Normally the spirit lets the flesh live its own life; but "when the actions of the flesh are a bar to the ends of the spirit," or "if some action of the flesh is necessary to achieve the ends of the spirit," the spirit "gives commands" to the flesh that either inhibit its action (as when fasts are imposed on it) or force it onwards (as to a martyr's death). In the same way the spiritual power "does not intervene in temporal business, but allows everything to go as before the two powers were united, provided temporal affairs put no obstacle to spiritual ends or are not necessary to achieve them. In these latter cases the spiritual power can and ought to coerce the temporal in every way that may seem necessary in the circumstances."

It is evident that Bellarmine reads his whole theory into the ancient metaphor, regardless of the fact that the metaphor bulges at the seams in the effort to contain a whole theory, when in fact it can serve only to convey a central Christian intuition-the primacy of the spiritual, and the fact that this primacy is maintained by spiritual means for spiritual ends. The metaphor cannot sustain the burden of manifesting the precise manner and extent of the subordination of the temporal to the spiritual power. And in one respect it works against Bellarmine's theory; the spirit does not use corporal means to coerce the flesh into subjection, nor can it, for instance, "depose" a recalcitrant arm and command the substitition of another. However, my essential point here is that Bellarmine's development of the metaphor illustrates his overarching concept of social organization: "The two powers in the Church are as spirit and flesh in a man." This statement does not derive simply from Catholic doctrine as such, but from the medieval fact.

${ }^{46}$ Cf. De S. Pont., V, 6, pp. 531-32. 
The same unitary concept of society appears constantly as a first premise. It is invoked against Barclay's coordinationism: "The fact is that the political commonwealth and the ecclesiastical commonwealth make one Church, not two; and of that one Church the head is the Vicar of Christ, the successor of St. Peter." ${ }^{47}$ It is used to disallow Barclay's idea of a simple bond of charity joining the two powers:

This would be correctly asserted if the political and ecclesiastical power were of the same order, and if they made, as it were, two separate commonwealths, like the Swiss cantons. But from the Scriptures Popes and kings, clergy and laity, once reborn in Christ, form one commonwealth, one city, one house, in fact one body. And the spiritual and temporal powers do not come together in the Church as two commonwealths unite to form one confederation, but as spirit and flesh unite to form one man. ${ }^{48}$

Again the hierarchy of the two powers - the major point of the argument-is invested with a particular modality, inasmuch as the two powers are conceived to be "within the one Church." And the subordination of the royal power is made to rest on a typically medieval reason: "... lest there be two heads in one body." 49 The factual premise of this unitarism appears again in the book, On the Translation of the Roman Empire:

... when princes are Christian and are numbered among the children and members of the Catholic Church, these two powers come together and are united to each other in such a way that they make one commonwealth, one realm, one family, in fact one body; for as the Apostle says (Rom. 12), we are one body in Christ and members each of the other. In this mystical body of the Church the ecclesiastical power is as the soul and the political power as the body. ${ }^{50}$

To modern ears, this use of "mystical body" is startling; to Bellarmine it was a commonplace. Finally, a quotation from his Examen of Widdrington's book shows once more how this overarching concept is woven into his status quaestionis:

By the 'Christian people' I did not mean simply the common people who are subject to a political ruler, but the head and members of the body of the Church,

${ }^{47}$ De potestate, V, p. 280.

4" Ibid., XIII, p. 297; the modification of the Gelasian formula, "hic mundus" (cf. Lo Grasso, Ecclesia et Status: Fontes Selecti [Romae, 1939], n. 96) to "eiusdem ecclesiae corpus" is clearly noted, perhaps for the first time, in the Relatio of the Synod of Paris to the Emperor Louis in 829 A.D.; cf. the text in Lo Grasso, op, cil., n. 184.

"De potestate, XIV, p. 299.

${ }^{50}$ De translatione, XII, p. 80. 
that is, the entire Christian commonwealth with its spiritual and temporal rulers. Accordingly, I never debated the question whether a political community could in a particular case depose its political ruler; for this question is none of my business. I was discussing the question, whether the Christian Church, which includes clergy and laity, Popes and princes, could elect and tolerate an infidel king. ${ }^{51}$

These citations may serve sufficiently to show that Bellarmine, though he conceives his questions in terms of principle, conceives it also in terms of the concrete medieval hypothesis. The Catholic principles are interpreted within a particular universe of discourse, the one ecclesia that was both Church and State. The operative principle of its unity was the spiritual unity of the Church herself; in fact, political unity was but an aspect of Christian unity. In this pattern of thought, men were indeed subject to two allegiances, but they were not members of two societies, two autonomously organized bodies with distinct principles of unity; for there was but one body and it could have but one head. The title to membership in the one body, in both of its aspects, was rebirth in Christ, baptism; it made men homines politici, as well as homines christiani. Civil status and religious status implied one another and were indivisible; one had status within the Church or one had no status. Extra Ecclesiam mulla salus, and extra Ecclesiam nullum ius.

However, the unity of the "two parts of the same one commonwealth" was established, not simply by baptism as the title of admission to both, but also and more particularly by the oneness of the head, the Pope, and his power of command over the subordinate political power. In the oneness of the head the dualism was reduced to unity; and this reduction of all things to unity was the ineluctable medieval drive. To Bellarmine, as to Boniface VIII, the prince is not "head" of a "body" politic; for there is only the one body, and it is mystical, and it cannot have two heads but only one. The subordination of prince to Pope is therefore a necessity, in order that the body may be one. Thus the celebrated argumentum unitatis appears even in Bellarmine. It appears, of course, in an attenuated form. He does not indulge in the fine-drawn speculations about the lex unitatis that delighted his forbears; nor does he, like Boniface, appeal to the Blessed Dionysius, or to the need of rejecting the Manichean impiety of

"Examen, IX, p. 371. 
"fashioning two principles." ${ }_{52}$ His firm political philosophy saved him from all that; but so powerful was the spell of the argumentum unitatis and so important its place in the medieval tradition that it still had hold of a man of the sixteenth century. It is the premise of Bellarmine's theology of the indirect power; it sets the framework within which he vindicates the two cardinal conclusions of his theory-the papal right to depose princes, and the prince's duty to exterminate heresy. His argument does not proceed simply in terms of an abstract "thesis," but distinctly in terms of a concrete "hypothesis," a particular historical realization, a time-conditioned mode of organic religio-social organization. He does not pause to consider whether the medieval situation, described in his documents, was normal and normative; and if so, how far. He simply took it as it was, thinking the while that it still was, or at any rate soon would be again.

\section{BELLARMINE'S ARGUMENTATION}

It is not surprising that Bellarmine's argumentation in support of his theory should reveal the influence of the same overarching concept that gives its cachet to the theory itself. In the Controversy, "On the Roman Pontiff," he has two lines of argumentation-first a series of five "reasons," and then a series of twelve "examples." His proof rests on the examples; in the preface to the Examen of Widdrington's book he gives it to be understood that he does not consider his reasons apodictic: "Even though the five reasons which I long ago brought forward for the power of the Pope in temporal affairs were weak, as William (Barclay) and Roger (Widdrington) strive mightily to prove, I would not for that reason alter my views, nor would the common cause of Catholic writers collapse. For I do not put my chief reliance on my reasons, nor does the common cause depend on me alone." 53 His basic appeal is to the action of the Church as the expression of her doctrine.

\section{The Five Reasons}

Three of the reasons need not long detain us. The third in order is in substance the statement that a non-Christian king within the

s2 Unam Sanctam, Lo Grasso, op. cit., nn. 432-37.

Examen, Praef., p. 359. 
Christian commonwealth is an absurdity, and a dangerous one at that. Moreover, "it is just as dangerous to elect a non-Christian king as not to depose one, as is well known"; hence "Christians" are bound to depose the non-Christian king who is a threat to faith. This forthright parallel between not electing a king and deposing one is a bit disconcerting; moreover, the appeal to "danger" as a basis of right and duty leaves open the question of the means that may legitimately be taken to ward off the danger. ${ }^{54}$

The fourth reason is not so much theological as constitutional; it is premised on medieval public law, and resonant of feudal fides and diffidatio:

When kings and princes come to the Church in order to become Christians, they are received under the express or tacit agreement that they subject their sceptres to Christ and promise to preserve and defend the Christian faith, even under pain of losing their kingdoms; consequently, when they become heretics or are a hindrance to religion, they can be judged by the Church and even deposed from their office of government; nor is any injury done them if they are so deposed. ${ }^{55}$

The argument is valid enough in the hypothesis that political sovereignty is constitutionally conditioned on fidelity to Christian faiththe medieval hypothesis that even Henry IV did not dare contest.

The fifth reason derives from the Pasce oves text of St. John. To the supreme pastor a "triple power is necessary": over wolves (heretics) to exterminate them; over rams (evil princes), to expel them from office; over the sheep, to command them to do their duty according to their state (which, for princes, means to punish heretics). ${ }^{56} \quad$ This is a good piece of allegorism in the medieval manner, but hardly exegesis. Above all, one cannot attach, by lines of exegetical necessity, the stake and the rope, or the ius emigrationis, or even civil disabilities on religious grounds, to the sweet command of Christ to the Supreme Pastor. We have here echoes of the Iron Age of Christendom, in which are mingled other accents than those of the voice that spoke to Peter.

These last three reasons prove chiefly how closely Bellarmine stood under the influence of a certain time-conditioned line of argument in this matter. His first two reasons are more formidable, though even they do not shake themselves loose from contingent elements. The

st De S. Pont., v, 7, p. 533. is Ibid., p. 534.

is Loc. cit. 
first is directly the celebrated argumentum unitatis. It proceeds from a premise of fact: "When both powers are part of the same respublica christiana, the civil power is subject to the spiritual power." Three reasons are given; the second and third are the statement that this subjection is a requirement of the unity of "the one Church"; the first is from the primacy of the spiritual end over the temporal end, whence follows the primacy of the spiritual power within the "one body."

This last argument is classic; but in modern thought it is proposed in a different context, not that of the "one body." With Leo XIII, for instance, the basic argument for the "orderly relationship" of the two powers proceeds, not from the fact that they are "parts of the one Christian commonwealth," but from the fact that "they both have power over the same men," ${ }_{58}$ who are Christians and citizens; if the two powers that rule man are "separated," he will be torn apart. Bellarmine, good medievalist that he was, never uses this Leonine premise. Whereas Leo argues, "Because the two powers have the same subjects, they ought to be united," Bellarmine argues in one place, "Although both powers have the same subject, nevertheless they are distinct." " The difference measures all the distance between the sixteenth- and the nineteenth-century problematic. Bellarmine regards the dual end of the one body, Leo XIII the dual end of the one man. The latter view is more personal, juridical, profound, capable of leading to more nicely adjusted conclusions because more respectful of the legitimate autonomy of man as citizen.

In Bellarmine's view the temporal end of the body tends to become simply a means, precisely because of its subordination within the one ecclesia, whose higher end tends to become, not simply a necessary point of reference but a principle of absorption (albeit casu) of the temporal by the spiritual. In the "one-body" framework, the legitimate autonomy of the temporal, as not merely a means but an intermediate end, valid in its own right, tends to be overshadowed. And as soon as the temporal life of human society is regarded simply as a means to the spiritual life of the Church, one rapidly concludes that

${ }^{57}$ Ibid., pp. 532-33.

${ }^{58}$ Immortale Dei, Lo Grasso, op. cit., n. 656; Liberlas, ibid., n. 674.

${ }^{69}$ Hier. Doron, XVI, Auctarium, p. 235; this is Bellarmine's most incisive statement of the distinction of the two powers. 
the temporal power is merely an instrument of the spiritual power. The conclusion is much too rapid; the subordination of the temporal power to the spiritual is not that of instrument to principal cause, as the subordination of the temporal to the spiritual end of man is not that of means to end. My point here is simply that the concept of subordination of powers, as following from the subordination of their ends is a flexible concept; its content will vary with the overarching concept of the society within which the subordination is effected. In Bellarmine's concept of the "one society," the subordination of the temporal power is necessarily more rigid and extensive than in the dual-society theory that was at once a later development and a return to earlier ideas. The classic argument ex finibus requires, I think, more delicate handling than he gave it; one cannot rush from it to detailed conclusions.

Bellarmine's second argument has likewise become classic; it is from the concept of a perfect society: "The ecclesiastical commonwealth ought to be perfect and sufficient unto itself in relation to its own end"; but "the power of using and disposing of temporal things is necessary for its spiritual end"; consequently the Church has this power, and-he hurries on-it extends to the deposition of rulers and the right to command the use of the temporal sword, "when a necessity of the Church requires it." ${ }^{60}$ Of all the classic arguments this is perhaps the trickiest; for it can readily be pushed to the point of fallacy, the classic fallacy being, of course, its use to prove the Church's possession of ius gladii. The concept of the Church as a perfect society is not an a priori concept, to be laid down forthwith as the premise of deductive argument: "Because the Church is a perfect society, therefore it has such-and-such a power." The question must always be raised, whether that power is part of the perfection of the Church, consistent with its nature as a kingdom not of this world, and proportioned to its supernatural and transcendent end? Actually, the perfection of the Church as a spiritual society is established a posteriori, from the possession of the powers which, in point of fact, were communicated to her by Christ. Otherwise, in our present matter one could easily bring in the intolerable concept of a raison d'Eglise, and make the Church a sort of Machiavelli $d$ rebours, to whom the necessity

${ }^{60}$ De S. Pont., V, 7, p. 533. 
of an end justifies any means taken to achieve it. Pushed still farther, the argument would cause the authority of the Church to appear as sheer power, limited only by the resistance that might successfully be opposed to it on the part of the secular order. The concept of necessitas Ecclesiae as the basis of ius Ecclesiae is a dangerous one from the philosophical standpoint; for in the delicate matter of means and ends necessity is not the sole consideration. It is also dangerous from the practical standpoint, especially when it leads to the use of Caesar to defend or further the things that are not Caesar's. One cannot risk erecting a lack of faith into a juridical principle; and there can readily be a lack of faith involved in the supposition that it is "necessary" for the Church to seek her supernatural ends, which are secured only through man's free obedience, by appeal to the material coercive force whereby the kingdoms of this world achieve their ends.

Bellarmine's use of the "perfect-society" argument is probably immune from fallacy by reasons of its perspectives, which are those of the one ecclesia. I suspect that the necessitas Ecclesiae on which he bases his attribution to the Church of the power to command the temporal sword is in reality the necessity of the concrete Christian commonwealth, the one body of which he constantly speaks, wherein the spiritual and temporal powers are united for a common end, in regard of which each has a distinct function. This ecclesia is a perfect society not only in concept but in point of fact and by public law; for it has at its disposal a temporal sword pledged (as he says in his fourth reason) to the conservatio ecclesiae, the good of the total commonwealth with its indivisible parts. I am not, of course, maintaining that this interpretation of Bellarmine's use of the "perfect-society" argument results altogether clearly from his text; it is more a matter of context. In fact, it is part of my contention that the clarity of all Bellarmine's arguments as well as the definitiveness of his whole theory, is considerably blurred by his acceptance of the one-society theory as the premise of his thought.

Perhaps, then, Bellarmine was well advised in not pinning the validity of his theory to the validity of these five "reasons." The only one that really touches the essential and permanent point of doctrine is the argument ex finibus; it strikes through to the necessity of unitas ordinis between the two powers, and establishes the fact (not 
yet the content) of the subordination of the temporal and the primacy of the spiritual. Then, as supported by the "perfect-society" argument (whose essential contribution is the idea that the Church's sovereign spiritual authority is universal in its scope), it leads to the conclusion that the primacy of the spiritual means a power on the part of the Church to judge, direct, and correct the political life of man, wherever the political touches the spiritual. This is perennially true. But the perennial truth gives rise to the perennial question: how is this direction and correction of man's political life to be effected? Bellarmine give his answer in terms of the direction and correction that were proper to that historical realization which he found in his booksthe respublica Christi, inspired by the splendid idea of the "one mystical body." The difficulty is that this historical realization, for all its splendor (with which was mingled an immense amount of misery) was not in all its details the incarnation of absolute divine intentions with regard to the relations between spiritual and temporal. There were in it contingent, relative, time-conditioned elements. And the element of the contingent in it necessarily imparts an element of contingency to the construction that Bellarmine erected on it.

\section{The Twelve Examples}

At that, one must not minimize the difficulties put to Bellarmine by his sources; this remark leads us to consider the twelve "examples" that are really the basis of his case. ${ }^{61}$ They fall into two groups. In the first group of five, two are from the Old Testament. Today we are chary of conclusions as to the organization of a Christian society drawn from happenings in the Jewish theocracy; granted that King Ozias was exiled as a leper by priestly sentence (II Par. 26:16-23) and Queen Athalia was slain by order of the priest Joiada (II Par. 23:14-15), it hardly follows that Gregory VII was right in deposing Henry IV, or that Philip II's persecution of Jews proceeded on scriptural warrant. Nonetheless, these arguments from the Old Testament had an immense influence in the Middle Ages; curialists and regalists matched texts with great learning and zeal.

The third example is the famous incident of Ambrose and Theodosius; here we have the temporal power brought under moral judgment ${ }^{61}$ Cf. ibid., 8, pp. 534-37. 
by the Church and visited with a spiritual penalty. The fourth example is a particular law of Gregory I, whose tenor is obscure. ${ }^{62}$ And the fifth is the excommunication of Leo the Isaurian by Gregory II; here a spiritual penalty appears as having temporal consequences, the loss of the revenues of Italy. None of these examples supports Bellarmine's theory in its full amplitude.

The second group of seven are all examples of papal action in the founding and rule of Western Christendom: the deposition of Childeric by Zacharias, the transfer of the Empire to the Germans by Gregory $\mathrm{V}$, and four of the string of depositions in the Middle Ages: that of Henry IV by Gregory VII, of Otho IV by Innocent III, of Frederick II by Innocent IV, and of Louis of Bavaria by Clement VI. These are the real foundations of Bellarmine's case; and among them the actions of Gregory VII, Innocent III, and Innocent IV are leading. $\mathrm{He}$ appeals to them again (under omission of the others, save the action of Gregory II, and with the addition of Urban II's deposition of Henry I) in the De Potestate Papae, where his point is to show their support by synodal or conciliar authority. ${ }^{63}$ In substance, then, Bellarmine derives his theory, in what is special to it, from the most resounding acts of the medieval papacy in its most imperial-minded representatives.

This must seem a narrow basis of argument. After all the six hundred years between Childeric and Louis of Bavaria are not long enough to constitute Catholic tradition. Moreover, the circumstances of those centuries were exceptional; at their outset, the Papacy stood "between a dying system and one waiting to be born," as the only living social and cultural force left after the complete collapse of a lay civilization; it acquired political status by default and maintained it by necessity - not that of the Church but of civilization itself. Finally, the theological tradition to which Bellarmine had to turn for clarification of the meaning of papal acts during this abnormal period was itself extremely confused. Being a controversialist and not an historian of dogma, he could be content to allege against Barclay "more than seventy" theological opinions as sufficient for his narrow polemical

\footnotetext{
22 Text in Lo Grasso, op. cit., p. 125, note 5; Bellarmine cited this privilegium because Gregory VII appeals to it as a precedent in his letter to Hermann, Bishop of Metz, loc. cit. ${ }^{6}$ De potestate, Praef. pp. $266-67$.
} 
purpose: "Since Barclay enters a blanket denial of the power of the Pope in temporal affairs, I for my part will cover it with a blanket assertion of that power, without greatly caring whether it be an absolute power or one that extends to temporal affairs only in their relation to the spiritual." As a method of controversy this was all right; but it evades a real difficulty. Among Bellarmine's vast array of authorities there were very considerable differences of opinion-greater differences than he, by reason of his simple purposes, was inclined to admit; ${ }^{64}$ and a careful sifting of them would be needed to discern the genuinely traditional elements of permanent Catholic doctrine.

At all events, these were the sources Bellarmine had to use; and their climactic datum was papal deposition of rulers. It raises a series of questions: What did the Popes actually do? Did they do it by right? And by what right? Above all, is the right by which they did it a permanent right of the Church, possessed independently of circumstances? Bellarmine's own answers are firm. The Popes, he maintains, at least on some occasions actually deposed rulers, not merely declared them deposed. And they acted by divine right: "Pope Gregory VII and Pope Innocent IV, in synod, before they passed sentence of deposition, stated whence they had the power to do it, and brought forward the word of the Lord: 'Whatsoever you shall bind on earth shall be bound also in heaven' (Matt. 16)." Indeed, they engaged the infallibility of the Church: "If the Church, believing and passing sentence in this fashion could be in error, it would certainly follow that the universal Church could be in error in a doctrine of faith and in its moral precepts." ${ }_{65}$ Finally, he contends at length against Barclay that this power was always present in the Church, even though not actually exercised in early times; it is a necessary element of her universal power of binding and loosing.

It was Bellarmine's misfortune that the matter of deposition of rulers had been thrust into the center of controversy. If this did not create a false problem, it certainly narrowed the whole issue to the point of

"Gierke's thesis is that the hierocratic view was "the general theory of the Church" (op. cit., p. 13); this is exaggeration and falsehood. On the other hand, Billot is short of the truth when he says it was the view of a few canonists, unversed in theology, "vix ac ne vix quidem attendibiles" (De Ecclesia, II [Prati, 1910], 80). A better idea of the theory both as a theory and as a tendency of thought, is given by J. Rivière, Le problime de l'Église et de l'Élat au temps de Philippe le bel (Louvain-Paris, 1926), passim.

« Examen, VI, p. 367. 
almost falsifying it; it tended to confuse the limited, juridical problem of the acts of the medieval papacy with the broader theological problem of the essential empowerments of the Church in regard of the direction of man's temporal life. Morever, even the narrow problem was not as simple as Bellarmine apparently thought it. For instance, the first question - what did the Pope actually do - is not simply a theological one, but rather importantly a legal one. Its solution depends in considerable part on an understanding of medieval constitutional law, especially of the right of resistance to political authority as contained in German feudal custom and developed by Christian law. Kern, for instance, puts the matter thus:

This view [that active resistance to government was compatible with, and an exigency of, the Christian conscience] could without difficulty be combined with the Germanic right of resistance. Although, as we shall see, it went beyond the latter in one important point, it shared with Germanic law the principle that the bad king deprives himself of the capacity to rule, and that by his own misdeeds or ineptitude he $i$ pso facto forfeits his royal rights. The unjust king ceases to be a king in the eyes of God; for king and right are inseparable ideas. The ruler dethrones himself by his own misdeed; he becomes tyrannus, usurper, a man using force without authority. ... The verdict of man, which decides that the ruler has forfeited his throne, or at all events, that he may be resisted, has only a declaratory, not a constitutive character. Unjust government is in itself void, and the verdict merely discloses the fact. But in the method by which the declaratory judgment was reached, the ecclesiastical doctrine of resistance introduced a very important advance over Germanic practice. In the Germanic theory of resistance there were no fixed forms, and the verdict was left to the legal convictions of the community, or rather each individual within the community. In the Church, on the contrary, there was an established judicial authority, which was competent to recognize the ruler's guilt, and so a formal judicial process against the king was possible. ${ }^{66}$

In this view, the authority of the Church appears as more obviously spiritual. Nor is Bellarmine's difficulty decisive - that Gregory VII and Innocent IV thought that they were actually deposing their Henries and their Fredericks. So indeed the tenor of their words might seem to indicate, though not with full clarity; ${ }^{67}$ at all events, their words may well be understood, as they themselves must have understood them, in the light of prevailing notions of constitutional law.

${ }^{*} \mathrm{~F}$. Kern, Kingship and Law in the Middle Ages, transl. Chrimes (Oxford, 1948), pp. 101-102.

${ }^{67}$ Cf. Lo Grasso, op. cit., nn. 264-65, 302 (Gregory VII), n. 395 (Innocent IV). 
Their fulminations retain all their terrible force, if understood as spiritual judgments, not of themselves constitutive of political effects; the political effects were declared, or at most entailed in virtue of public law, by the spiritual judgment. Finally, the thing that moved Bellarmine so much need not have moved him so far; I mean the papal appeal to Quodcumque ligaveris. The appeal is entirely understandable and right. Whether the papal sentence was constitutive or declaratory, its basis was something more than "historic right," as if the Popes' empowerment thus to act came only from constitutional law. Actually, their fundamental empowerment was from the divine law that confers upon the Church a universal spiritual jurisdiction; however, the expression of this jurisdiction in the constitutive or declaratory act of deposition ( $\mathrm{I}$ am not speaking of the antecedent act of excommunication) depended for its "rightness" on the juridical situation that actually existed at the time, when the Christian law was the foundational element of public law, and fidelity to it was the condition as well of legitimate sovereignty as of citizenship.

\section{The Ultimate Difficulty}

This, however, brings us to the basic difficulty in this whole matter. It is no great problem to explain how the medieval papacy acted iure, even iure divino; it is furthermore easy to show that its extensive tutelage of the political order was not only necessary in the circumstances but also largely beneficent in its effects. The problem concerns the permanence of its right of tutelage. At this point Barclay puts forward his "insoluble argument, that for almost a thousand years there was in the Church neither use nor instance nor even mention of any such papal power (to depose princes)." 68 His conclusion is that the power is a usurpation, of which Gregory VII was the author. The conclusion, of course, is false, but the difficulty is real.

To it, Bellarmine says, "there is one simple answer: during that period the Church could not use her power," though she had it all the time. " "If the Christians of old did not depose Nero and Diocletian and Julian the Apostate and Valens the Arian and their ilk, this was because they lacked political power (vires temporales)," although they they had the right.70 "In those days the use of this power against

${ }^{68}$ De potestate, VI, p. 280.

${ }^{60}$ Ibid., p. 281.

${ }^{70}$ De S. Pont., V, 7, p. 535. 
princes was lacking, because there were no (Christian) princes; but the power itself was not lacking; for to have a power is one thing, to use it is another." 71 And he invokes the authority of St. Thomas: "At that time the Church in her youth had not yet the power to restrain earthly rulers. Hence she allowed the faithful to obey Julian the Apostate in things not contrary to faith, in order that a greater danger to faith might be avoided" (II-II, q. 12, a. 2 ad 1m). Bellarmine admits that "Popes and ecclesiastical writers of an earlier day" said nothing about the matter; but "just as they did not affirm, so they did not deny" this power of the Church. At all events, the power was later asserted, and this is the basis of his theological argument: "The Church is the same, and the gates of hell will never prevail against her. ... Hence he has not the right concept of the Church who admits nothing but what he reads about as having expressly been written down or put into action in the ancient Church; as if the Church of later times either has ceased to be the Church or has no authority to explain and make clear, and even to settle and enjoin, things that have to do with faith and Christian morality." 72

One wonders whether this "simple answer" is not a bit too simple. Even if it be purged from the taint of opportunism that might attach to it if understood crudely, it seems to imply an unnecessary "fixism" in the Church - a "fixism" that is less admissible in the political theology of the Church than elsewhere. Are there not some distinctions necessary here, and some refinement of formulae? For one thing, it cannot be said that the early Church was conscious of possessing any such extensive powers over the temporal order as Bellarmine attributes to her. I dare say that Gelasius I, for instance, would have been astounded, had he been told that he had the right and power to depose Anastasius. ${ }^{73}$ St. Augustine was content to justify the invocation of the secular power against the Donatists simply by an argument $a b$ eventu, without troubling to make a juridical case. And it has been

"De potestate, VI, p. 280.

Ibid., III, p. 274.

${ }^{73}$ Tellenbach undercuts the truth in his statement: "Gelasius I was extremely conscious of his sublime dignity, but neither he nor the Fathers of that age had yet reached the idea that on earth the Church was supreme over princes and emperors" (Church, State and Christian Society at the Time of the Investiture Contest [Oxford, 1940], p. 36). Gelasius had indeed no idea of a spiritual jurisdiction with such extensive reach into political life as Gregory VII later exercised; but his consciousness of the primacy of the spiritual was firm. 
suggested that even the bishops assembled at Compiègne in 833 to judge Louis the Pious probably had no clear idea of any power actually to depose him. ${ }^{74}$ Surely, then, there was development in the consciousness of the Church in regard of her power. This makes no difficulty. But was there development in regard of the possession of the power?

Here a further distinction is needed; Bellarmine himself, in fact, suggests it in meeting Barclay's objection that the Scriptures contain no commission, either express or tacit, given to the Pope to depose rulers. Bellarmine's answer is: "Indeed he has an express commission, but one expressed only in general," namely in his general commission as claviger and Supreme Pastor. ${ }^{75}$ Here Bellarmine touches his central thought, the essential denial that he opposed to Barclay's coordinationism. Barclay maintained that "the ecclesiastical and political powers are distinct and separate by divine law, in such wise that, although both are from God, each is contained within its own boundaries and cannot by right invade the territory of the other, nor has either any power of command (imperium) over the other." 76 To this error, I say, Bellarmine opposes the central Catholic doctrine: "We deny that there can be a supreme ecclesiastical or spiritual power which does not somehow have joined to it a power of disposing of temporal things, that is, in their relation to the spiritual." 77 In other words, as soon as one admits the existence in the Church of a supreme spiritual sovereignty, one must admit that this sovereignty may legitimately reach into the temporal life of Christian society, there authoritatively to touch the spiritual issues arising in society. In this sense Catholic doctrine is "fixed"; the whole political theology of the Church revolves about this essential, permanent, unchanging right and endowment of the Church. It is an endowment transcendent to circumstances, independent of historical contexts; the Church had it in the days of Nero as well as in the days of Gregory VII; as a necessary adjunct of her supreme spiritual power it is part of her very constitution. This is the central Catholic truth that Bellarmine, at bottom, wants to vindicate.

However, this permanent right of the Church in temporal affairs is quite unspecified; and by it the Church was not necessarily empowered to depose Nero in the first century or Diocletian in the third. Here Bellarmine goes too far. The Church was not held back from these

${ }^{74}$ Cf. C. Journet, L'Église du Verbe Incarné, I (Paris, 1941), 279, note 2.

75 De potestate, V, p. 279.

${ }^{76}$ Ibid., II, p. 268.

${ }^{7}$ Ibid., V, p. 280. 
acts simply because they were not opportune ${ }^{78}$ there was a genuine defect of right. As a matter of fact, in their particularized form the rights of the Church in the temporal order are not properly endowments of the Body of Christ in her transcendent aspect, but of the Body of Christ as incarnate in space and history and the human community in the dissolving phases of its life. They are the endowments of the Church in her temporal aspect, because they are endowments in regard of the temporal order, in which the Church is perpetually engaged, at the same time that she transcends it. But the temporal order is not an unchanging absolute; it is a thing of growth and contingency, shot through with relativities. Hence certain particular rights of the Church in regard of the temporal order necessarily display an element of relativity; they are asserted in regard, not of "the temporal order" in the abstract (there is no such thing), but of the temporal order of a given time and place by the Church of that time and place. Always the root of their assertion is absolute and unchanging-the supreme and universal spiritual power of the Church; but the particular rights that are asserted have not the same absoluteness or unchanging quality.

As a principle, this is admitted by all. For instance, the Church has not the same rights in regard of an infidel society as of a Christian one; this is the doctrine that Vittoria, after St. Thomas, vindicated against the hierocrats, who would have given the Church the power to annul, as illegitimate because unchristian, political sovereignties in infidel states. Relative to such societies, the Church has no such right. The same principle is true in regard of the various types of Christian society that are possible; if there should be a "new Christendom" in 2045 , one may not suppose that the Church would have the same rights in its temporal order that Innocent IV could assert in 1245. It is not enough to say baldly that she would not use the same rights - for instance, to depose rulers-although she would have them. The fact is that she would not have them. She would still, of course, have her supreme spiritual sovereignty and its necessary reach into the temporal order; but this particularization of it would be not merely inopportune, inexpedient, ineffective; it would be unrightful. To extrapolate for-

De potestate, III, pp. 271, 273-74; V, p. 279; VII, pp. 281, 282-83; XIX, p. 308; XXII, p. 313; De S. Pont., V, 7, 533; etc. 
ward in this matter is just as illegitimate as, with Bellarmine, to extrapolate backward.

In the zeal of controversial argument, then, it would seem that Bellarmine confused the absolute and permanent with the relative and contingent. Against Barclay's coordinationism he took his stand on the absolute ground of the primacy of the spiritual and the subordination of the temporal to the spiritual in what concerns the spiritual. But his feet slipped, so to speak, off this permanent ground onto a more shifting terrain. He had, of course, to go off onto this latter footing; he had to defend the acts of the medieval papacy as "rightful." So they were. And their rightfulness derived basically from the absolute truth of the Church's spiritual sovereignty. But the particular concretization of this absolute truth in the papal right of deposing rulers need not, and cannot, be defended "absolutely," or made a permanent endowment of the Church. The actualization of this particular right - that is, the Church's actual possession of it-was dependent on a particular set of historical circumstances, on a special relation in which the Papacy of the time stood to the temporal order of the time.

I might better say, to the temporal disorder of the time. Here is a consideration that is frequently overlooked-Bellarmine overlooked it-but that is necessary in order to realize how much of "hypothesis" there was in the medieval situation, and how unsure, because relative, are the premises of argument afforded by it. It is not merely that the particular rights of the spiritual power over the temporal were conditioned by the fact and theory of the "one society," which, as both fact and theory, was a relative, contingent, time-conditioned thing. There is also the fact that certain of these rights-notably that of deposition - grew directly out, not of any "thesis" (which connotes an idea of perfection of entity), but out of an imperfection, and in this sense a disorder in society - the disorder proper to immaturity. In other words, they were rights possessed in consequence of a lack of development in the institutionalization of the political order. They were, therefore, rights possessed in hypothesi, because, I take it, the rights that the Church possesses in thesi suppose not only her own perfection as a society but the perfection, too of the State-the development of its institutions in accord with the dynamisms of reason, justice, and political prudence. 
This is no place to do a long piece of political history, but this much may be briefly said. In the Middle Ages the one effective institution for the control and direction of society was the monarchy: "At no other period were active policy and progress in government so dependent on the personality of the king as in the early Middle Ages, with their lack of a bureaucracy and their poverty of initiative on the part of the Estates."79 Bellarmine himself registers the fact, characteristically, in a citation from the old Testament: " 'Qualis enim est rector civitatis, tales et habitantes in ea' (Eccles. 10); unde est illud: 'Regis ad exemplum totus componitur orbis." "\$0 This is why the Church's preoccupation with the temporal order was in reality a preoccupation with the king. We say today that what the Church wants is "a just temporal order"; in those days what the Church wanted was the rex iustus; for "the king's justice" was the source of all rights and order in the community.

Now, the king did indeed acknowledge himself as bound by law; the concept of the irresponsible king, rex legibus solutus, was a later development and a piece of neo-paganism. However, the medieval problem was how to keep the king obedient to law, how to compel him to do his duty of justice, how to punish his breaches of duty, how to get rid of him if he were incorrigible or useless. This, of course, is a perennial social problem; we have it today in another form. Basically, it is a problem of the institutionalization of society; and in a mature society it is solved by the creation of institutions within the political order that will serve to insure the supremacy of law and its due processes against the encroachments of force, wielded either by the ruler or by other agencies. This is an exigence of rationality itself, a demand of the autonomy of the political order when developed to maturity, that it should be "directed and corrected" from within itself, by the operation of its own political institutions. So a mature man is directed and corrected from within; it is the child that is under complete tutelage.

The political defect of the Middle Ages was that there were no effectively organized political institutions that could contrive to keep the monarch subject to law, or do away with him if he became a tyrant. There were under Germanic law various institutionalizations of the ${ }^{7}$ Kern, op. cit., p. 81.

${ }^{80}$ De S. Pont., V, 7, p. 533. 
"right of resistance," but they were largely ineffective, and even when effective led rather to further disorder. Moreover, as Kern rightly says, even by itself, "the right of resistance was only the acute symptom of an organic ill in the early medieval body politic." ${ }_{11}$ What was needed was not merely a technique of organizing resistance to tyranny, but a technique of making tyranny impossible - therefore a preventative technique, not merely a repressive one. It was 1215 before the needed institution theoretically came into existence, in the treaty which John Lackland concluded with his barons at Runnymede. However, the famous Article 61 of Magna Carta, for all its greatness as an historical achievement, provided an institutionalization of the supremacy of law that was defective both in theory and in practice; at best it was an emergency measure. And it was only later that the requisite institution was developed in theory and practice - the constitutional monarchy, wherein the consensus of the people, as a limiting principle set to sovereignty as well as a cooperating principle of government, was organized in the form of an assembly of Estates, or Parliament. Our modern development of democratic political institutions carry on the same line of solution to an ancient problem.

It is within the framework of this progress to a solution of a basic political problem that one must situate the papal right to depose rulers, asserted in the Middle Ages. Actually, what the Church did was to step into a political vacuum, created by the absence of a political institution able to constrain the monarch to obedience to law. She found a vague and chaotic Germanic right of popular resistance to unjust authority that was insufficient for its own purposes, and she transformed it into a new system of regular judicial procedure for the restraint, deposition, and punishment of kings. The new system was conceived in the interests of the populus christianus; its political legitimacy was rooted in the fact of Christian faith as the foundation of the order of temporal society, just as its spiritual legitimacy was based on the supreme spiritual power of the Church. But the system was in a genuine sense a makeshift, a merely transitional institution, made necessary by a defect in the political order. It was a natural development in the circumstances, but it was really thrust both on the Church and on the political order as a development alien to the native tendencies of each. The rational dynamism inherent in the social process

${ }^{81}$ Kern, op. cit., p. 131. 
tends to a political order that regulates itself from within by political institutions through whose instrumentality "power" is made subject to "law." Hence the assumption by the Church, which is not a political institution and does not stand within the political order, of the functions of such regulative institutions introduced an alien element. On the other hand, the supernatural dynamism inherent in the Church tends away from the assumption of a political tutelage of the temporal order, and from actual management of its processes.

From this point of view the medieval "order" was essentially unstable. The primacy of the spiritual was being asserted in a manner that, abstractly and in thesi, clashed with the autonomy of the temporal. The difficulty was that the temporal was not prepared to be autonomous; it had not built up the institutions that would enable it to dispense, as it were, with foreign aid. Consequently, in hypothesi the Church had to supply the defect. Concretely, if the Pope did not depose the ruler grown tyrannical or unjust or heretical or useless, there was no other way to get rid of him. Or - to go back to what was in effect the beginning of this peculiar medieval situation - in 751 there did not exist any popular institution that could deprive the Merovingian dynasty of its blood-right to the throne, even though the last Merovingian, Childeric III, was politically useless, and the rule was actually in the hands of the Mayor of the Palace. It was in this political impasse that the Franks turned to Pope Zacharias, who was the only "institytion" capable of setting aside the principle of legitimism in favor of the principle of suitability. Then, "by his apostolic authority (the Pope) gave orders that Pippin should be made king, so that the order might not be disturbed." \$s The Pope brought political order out of political disorder; and his apostolic authority had to come into play, for only the authority of God, resident in the Church, could thus tamper with the sacred rights of the reges criniti. The whole démarche had its origin in a defective political situation, in which the Church occupied a peculiar place; and the precedent was powerful.

But here we have not simply a serene assertion of an empowerment

82 I mean that these institutions are the immediate material and efficient causes of such regulation; they themselves need to be "informed" and "finalized" by the Christian truth and spirit; this Christianization of institutions $a b$ intra is the contemporary problem, and the decisive form that the problem of the indirect power has assumed in our day.

Annales Laurissenses, A. 749; cf. Lo Grasso, op. cit., n. 132. 
with which the Supreme Pastor is invested, independently of all temporal circumstance, by the Pasce oves. Actually, it was a last-resort remedy applied to the "organic ill" of the political order of the timethe lack of institutions to insure its own stability and carry on its own processes. The authority of the Church was filling a political vacuum; it was the only power in the "one society" that could do so. And in the circumstances, which gave specification to its native empowerments, it acted rightfully, iure divino. However, the right had its being, and was asserted, relatively to a particular segment of mankind's political development - the age of the respublica christiana of a special type, in which, moreover, the civil order was in an adolescent stage. In its amorphous state, with its "habits" (institutions) undeveloped, it stood in need of a tutelage of special kind, which only the Church could supply. The direction and correction which it is her permanent right to give assumed particular contingent forms, notably in papal deposition of rulers. Within the "one society," an ecclesiastical institution, the sacerdotium, assumed the status and functions of the political institutions that were not there.

However, adolescence is not a permanent condition in human life, individual or social; nor are the techniques for the management of adolescents normative in regard of adults. Adolescents grow up; they may grow up to be good or bad, but the fact that they grow is itself good. Self-consciousness comes, and with it the development of processes for the management of self; the processes may lead to what is good or what is bad, but as processes they must be respected. The adolescent, as he grows, differentiates himself from the parent; and though the general parental right of direction and correction remains valid, certain expressions of it are no longer valid, no longer "right." They were rights only in the hypothesis of adolescence. So it was with the civil order. It grew up; it became a State; and as a State it differentiated itself from the Church, as a society in its own right, with its own institutions to direct and correct its action. And its growing self-consciousness inevitably led it to reject the performance of certain offices in its regard that the Church, in default of other agents, had performed. One of these was ecclesiastical intervention against unjust authority, as an institutional procedure that once had political and 
constitutional status. This status was now denied it by the adult State, come into the consciousness of its maturity.

In itself, the denial was justified; and de facto it terminated the right of the Church to have its ecclesiastical acts recognized as having constitutional validity; the reason is that it terminated the hypothesis in which this right was valid. Moreover, of itself the denial to the Church of this particular, hypothetical right need not have entailed a denial of the absolute, permanent right of the Church to direct and correct the political life of society. Nevertheless, in the concrete the denial of the absolute right was associated with the denial of the relative one. This is the point that Bellarmine saw very clearly in his battle with James I. The denial of the papal right of deposition, required of Catholics in the Oath of Allegiance, could not in the concrete be made by them, because it meant in effect the denial of the spiritual sovereignty of the Church in itself and in its necessary reach into the temporal order; furthermore, in the concrete it meant stigmatizing as a usurpation the right that the Church had claimed and exercised throughout the whole medieval period. The situation was indeed tragic for the Christian conscience. Catholics had really been maneuvered into a false position; they were compelled to rally to the defense of an outpost that in 1606 could well have been abandoned, because its defense was part of an ancient war, long since concluded. However, its abandonment in the circumstances of 1606 would have meant in effect the surrender of the fort itself.

It is probable that Bellarmine did not perceive the full tragedy of the situation. As a controversialist, he took up the challenge as presented, and went all out in defense of the papal right of deposition as a permanent endowment of the Church. Undoubtedly it was such to him, as he saw it represented in the limited tradition that was closest to him - the tradition of the Christendom of Gregory VII and Innocent IV. He stood too close to this tradition to see how much of the hypothetical, the contingent, the relative it embodied, in consequence of its acceptance of the unitary, organic theory of society, and its limited political development and experience. Consequently, he was not content to defend, in terms of the problem as then presented, the relationships between sacerdotium and imperium, the rights of the Church in 
the political order. He implicitly accepted the terms themselves as permanent and unalterable in all their details, and hence he endowed all the details of the solution with the same permanence and unalterability. He knew that principles are always principles - a deposit, no whit of which may be surrendered. But he did not fully realize that history is only history - a process, no segment of which may be eternalized.

\section{CONCLUSION}

An appreciation of Bellarmine's political theology must needs be generous; here it may also be brief. His defense of the permanent and absolute principles on which that theology rests was brilliant and effective. The essence of the "common cause" that he defended was, of course, the distinction of the two powers. Bellarmine gave it a newly luminous statement by his emphasis on the purely spiritual power of the Church, and by his elaboration of Thomistic political philosophy. In this respect he effected a doctrinal advance within the Church herself, by finally disposing of the confusions and exaggerations of the hierocrats. Moreover, out of this doctrinal synthesis, by analysis of its terms, he drew a newly effective statement of the second great principle that is part of the Catholic "common cause"; I mean the primacy of the spiritual power and the subordination of the temporal power. Here he did a service not only to the Church but to the spiritual freedom of mankind, in that he set a stern barrier to the tyrannical pretensions of royal absolutism. His doctrine shattered all three elements of the theory of "divine right": the exclusive rightness of the monarchical form of government, the belief in an individual monarch's inalienable right to govern, possessed independently of human agency, and the assertion of the irresponsibility of the king - his absoluteness. Here was a political as well as a theological achievement of a high order.

Bellarmine's signal merit as defender of the "common cause" is therefore unquestionable. But questions may be raised concerning the peripheral positions he maintained - his theory as such. The primacy of the spiritual - the power of the Church to judge, direct, and correct the political life of society in all that touches the spiritual order-is an absolute principle. But it, and the subordination of the 
temporal that it entails, must be given a specific content; in fact, it has historically been given such a content by specific actions of the papacy. Here a problem of development arises: how much of this content is itself as absolute as the principle, and how much is relative? How much is permanent right on the part of the Church, and how much is contingent, historic right, that vanishes, as right, with the social and juridical situation that was the factual basis of the empowerment in question?

Bellarmine is less successful in wrestling with this difficult problem. He seems to have identified the principle itself with the contingent modes of its applications, and in defending these applications as right (which they certainly were), he gave them the status of absolute rights (which they probably were not). As visible in his thought, this confusion of the absolute and the relative was simply the reflection of the confusion in his sources; I mean the tendency of the medieval mind to regard as absolute what was only relative - the hypothesis of "one society," "one body," one respublica christiana that was both Church and State, within which the "temporal" was only a "power," a subordinate function in a whole, not the focus of an independently organized, autonomous body-in-its-own-right, with its own developed institutions and processes for achieving its own ends, which are only intermediate ends indeed, but ends for all that. Bellarmine, like his forbears, did not and could conceive of any but two forms of societythe pagan society of antiquity, and the Christendom of Gregory VII. Like his forbears, too, he believed that the medieval respublica Christi was destined to a perennial existence, troubled at times by disruption, but victoriously recovering.

This social hypothesis was the acknowledged framework of his political theology; and not recognizing it as hypothesis, he drew from it conclusions that he considered absolute. In the same way, from a study of the power of the Church over temporal affairs, as exercised within the framework of that hypothesis, he came to a description of the power of the Church ut sic, as necessarily consequent upon her unchanging constitution. He failed particularly to see how close a relationship there was between the powers assumed by the medieval Church and the structural and procedural weaknesses of the contemporary political order. Hence he did not see that these particular 
powers must pass-I mean the powers themselves and not merely their use - with the passing of the hypothesis of political weakness that was their temporal foundation. In fact, it was impossible for him to admit that they could pass; for he could not see how their passing could leave intact the essential right of the Church to direct and correct the temporal order. The false state of the question laid down by James I contributed powerfully to bring his thought to this impasse.

The two levels in Bellarmine's thought can perhaps been seen rather easily in one sentence in his early work, On the Translation of the Roman Empire. He says: "This whole matter [of the translation] depends on two assertions; first, that the Roman Pontiff is the father and pastor of the whole Church, that is, of all Christians; secondly, that the supreme pastor of the whole Church is set, not only over private individuals but also over Christian kings and emperors, in such a way that, if the cause of Christ and the Church demand it, he can strip them of their reign and empire, and transfer their royal or imperial power to others." " Up to the moment that he gets to the "ita" ("in such a way"), Bellarmine is on the plane of the absolute and permanent. And he voices the two central truths whose defense was his main preoccupation: the universal spiritual sovereignty of the Church, and the effective reach of this sovereignty to the king as king - that is, the subordination of the royal power to the judgment, direction, and correction of the Church in what concerns the spiritual. These truths are absolutely true; one could alter their statement today only to the extent of not speaking of regna and imperia, but simply of governmental power and social processes. If there were a Christian society today, these truths would be controlling in it, by means of techniques suited to the forms and processes of the society. However, as soon as Bellarmine gets to the "ita," and lays down particular consequences of these truths, and particular techniques for their application, he is on the plane of the relative, the contingent, the transitory. In 800 A. D., Leo III had a right to crown Charlemagne as Emperor of the Romans; but this was because it was $800 \mathrm{~A}$. D. If there were a Christendom tomorrow - a Christian world-government in a society whose every member was baptized - the Pope, for all the fullness of his apos- 
tolic authority, would not have the slightest shadow of a right to "crown" so much as a third-class postmaster.

If there are two levels of thought in Bellarmine's doctrine of the power of the Church over temporal things, it might be supposed that there would likewise be two levels of thought in his doctrine on the power of secular government, as the "sword under the sword," in what regards the spiritual unity of the Church and the integrity of her faith. But this is a subject for later discussion. 